\title{
ON THE NEXUS BETWEEN RISK TAKING AND PROFITABILITY: EVIDENCES FROM INDONESIA
}

\author{
Abdul Mongid* \\ STIE Perbanas Surabaya \\ Muazaroh Muazaroh \\ Stie Perbanas Surabaya
}

\begin{abstract}
This paper test interrelationship between risk taking and profitability (ROAA) using two stage regression. We study 150 bank sample for 2008-2014 from Indonesia. Instrumented variable is total risk taking (RT) and the instruments are asset size, equity to total asset, loan asset ratio, loan loss reserve, efficiency, liquidity. For macroeconomic variables, we use economic growth, Central bank -rate (CBDR) and inflation rate (CPI). We find a positive relationship between risk taking (RT) and bank profitability (ROAA). Further, the relationship between risk taking (RT) and profitability (ROAA) is endogenous. The result confirms that bank's motivation to take more risk is to earn higher profit. In addition, capital ratio is negative to risk taking (RT) and profitability (ROAA). Interestingly, credit risk taking is negative due to the high correlation with a problem loan (LLRGL). The cost inefficiency is negative to bank's profitability. Finally, for improving profitability, bank's manager should manage the operation better such as reducing problem loan and improving cost efficiency as these actions are more effective than taking more risk taking $(\mathrm{RT})$.
\end{abstract}

Keywords: Risk Taking; Profitability; Two-Stage Regression; Macroeconomic; Indonesia.

\section{INTRODUCTION}

Recent developments in the company performance evaluation, such as economic value added (EVA) and return adjusted risk of capital (RAROC), has been applied to provide new insight on how a bank operates and performs in competitive environment (Saha, Ahmad and Yeok: 2016). However. Traditional financial ratios and profitability indicators such as return on average assets (ROAA) or return on average equity (ROAE) are still regarded as the most reliable bank's performance measure especially among regulators. Rodríguez-Ruiz, Rodríguez-Duarte and Gómez-Martínez (2016) support the use of ROAA for bank performance as market based performance is not superior than accounting based. Further, Agarwal and Taffler (2008) confirmed that the accounting-based approach yield significant economic benefit over modern method known as market-based model.

The purpose of this study is to review performance indicators of different banks in comparison to their risk preferences using simultaneous regression (Two Stage Regression-2SLS). According to Maddala (2001), this technique can directly estimate the interrelationship between risk taking and performance. As risk taking serves as instrumented variables, the results correlate with the error term (endogenous) implies the traditional Ordinary Least Square (OLS) is not suitable. From risk perspectives, Greuning

*Corresponding author: Postgraduate Dept. STIE Perbanas Surabaya, Nginden Semolo 36 Surabaya, Indonesia 60118, email: mongide@perbanas.ac.id. 
and Bratanovic (2009) suggest that analysis of bank profitability should be embedded with risk-taking perspective. We replicate the approach of Booth, Fung and Leung (2016) who use a risk return framework to investigate the momentum-reversal phenomenon using U. S. stock returns. We adapt the approach for the banking industry in Indonesia. Using risk taking principle, we recognise the possibility or the choices of bank manager may bring negative effects such as loss or danger to the bank but it also produces higher profits either.Endogeneity of risk and profit is essential in the banking as banks serve as intermediation players. As intermediary, banks serve as size transformation, maturity transformation and risk transformation. Commercial banks by effectively appraising credit requests can channel funds into productive uses. According to Bhattacharya and Thakor (1993), benefits provided by financial intermediaries consist of reducing information and transaction costs, granting long-term loans, providing liquid claims and pool risks. It means, financial intermediary such as banking, generating profit from the risks they take.

Many papers discussed the determinant profitability based on macroeconomic, microeconomics or both that try to link the risk position to profitability. For example, Dietrich and Wanzenried (2011) using microeconomics and macroeconomic variable to investigate the determinant of bank profitability especially on the impact of global financial crisis (GFC). Petria, Capraru and Ihnatov (2015) apply risk as a determinant of bank profitability using linear regression. Similar work is done by Mongid and Tahir (2011) for ASEAN banking. However, their approaches are not yet considering the endogeneity of risk taking and profitability.

The problem of the research is whether there is a positive relationship between bank's risk taking position and profitability when bank specific variables and economic condition where the bank operating areembedded. Freixas and Rochet (2008) suggest banks operate in different economic condition own different preferences in risk taking and profitability. Most of previous studies (González, 2005; Dietrich and Wanzenried, 2011; Srairi, 2013; Petria, Capraru and Ihnatov, 2015) defined risk as ex post meaning the risk is measured using risk event data such as non-performing loan (NPL) or loan loss provision (LLR). Thispaper looks at the risk from different perspective (ex-ante) and measured as a summation of credit and operational risk. We exclude market risk due to data availability. According to Price, Waterhouse and Copper $(\mathrm{PwC})$, credit, liquidity and operational risks are the top three risks for Indonesian banks (PwC, 2015). It means market risk is relatively less significant. In addition, by elaborating credit and operational risk, the coverage of risk is more extensive. This approach is in line to Cole, Kanz and Klapper (2015) that apply risk taking as ex ante. These approach have not been applied for Indonesian banking case. We expect this work, using framework from Brown (1990), add a more empirical works on risk-taking and return relationship especially for Indonesia's banking.

\section{LITERATURE REVIEW}

Banking as intermediary institution is regarded as the most risky business. However, according to Santos (2000), Diamond and Rajan (2000), there are two types of intermediary function: brokerage and asset transformation activity. Brokerage function as represented by the activities of brokers and market operators, processing and supplying information. Asset transformation is a process of issuing claims against themselves, which differ from the assets they acquire. Brokerage is less risky than asset transformation. Risk is a condition in which there exists a possibility of deviation from a desired outcome that is expected or hoped for (Gallati, 2003). It is implied that banks have to manage the risks through appropriate structuring of their activities to maximize their profitability. As asset transformer, taking risks are necessary condition for making profit. Assuming a bank owns two choices, putting in 
cash which is no risk or making loan which is risky, bank will choose the last one as it generates profit. The trade-off between risk and return is always dilemmatic problem for bank manager.

The impact of liquidity risk on bank profit has been studied extensively. Shen, Chen, Kao \& Yeh (2009) investigate the relationship between bank liquidity risk and performance for 12 advanced economies over the period 1994-2006. They find that liquidity risk is the endogenous determinant of bank performance and the causes of liquidity risk include components of liquid assets and dependence on external funding, supervisory and regulatory factors and macroeconomic factors. Tan and Floros (2012) infer that liquidity position improve bank's profitability in China. Fadzlan and Khazanah (2009) examine the determinants of profitability of China banking and suggest that liquidity has negative effects on profit. Meanwhile, Ascharya and Naqvi (2012) suggest the link between liquidity, business cycle and risk taking are not linear and depends on the monetary policy where the bank operate.

A bank requires capital to run business. However, the impact of capital on bank risk and profitability are varied. Abreu and Mendes (2002), concluded that well capitalized banks take less credit risk so face lower expected bankruptcy costs and this advantage "translate" into better profitability. Athanasoglou et al (2008) find positive impact of capital on bank profitability. A bank with a sound capital position is able to pursue business opportunities more effectively and has more time and flexibility to deal with problems arising from unexpected losses, thus achieving increased profitability. Miles and Maecheggiano (2013) find negative impact of bank capital on profitability due to excessive capital. It means bank should own optimal capital to maximize profit. Watanabe (2007) finds that Japanese banks tended to shift lending to higher risk companies because of the risk that the latter would drive high risk firms into default, worsening the capital situation. Fadzlan and Khazanah (2009) and Muazaroh et al (2012) also found positive impact of capital on profitability. Trujillo-Ponce (2013) conclude capital is positive to profitability in Spanish banking.

The impact of capital on risk taking. Gambacorta and Mistrulli (2004) found no conclusive evidence about the effects of bank capital on risk taking behaviour. In contrast, Godlewski (2006) applied a two step logit model approach to study the impact of the regulatory capital and institutional environment on excessive risk, and they found a strong relationship between capital on risk taking andrisk taking on bank's default. Foos, Norden and Weber (2010) investigate the intertemporal relation between loan growth and the riskiness of individual banks. They found that past abnormal loan growth has a positive and highly significant influence on subsequent loan losses with a lag of two to four years. Berger, Klapper and Turk-Ariss (2009) studies the impact of competition in the credit market on bank behaviour toward risk taking. They find that competition increase bank behaviour to take more risk so the bank can produce more loans and securitize them to earn more profits. Tahir and Mongid (2013) unveiled that stronger capital banks take less risk taking. Abdul Wahab, Saiti, Rosly \& Masih (2017) study the impact of capital on risk taking. They find that higher capital growth and capital buffer increase risk taking. Excess capital provides an extra cushion take relatively riskier financial activities without breaching the capital regulation. Konishi \& Yasuda (2004) conclude that it is not the size of capital but stable shareholder is more important to risk taking.

Mongid and Santoso (2002) study the bank performance in Indonesia by applying risk adjusted performance measure. The study found that risk adjusted performance provides better insight to evaluate bank's performance. Lee (2008) underline the impact of size on risk-taking and profitability using data from Korean banking. Schaeck and Cihak (2014 ) conclude that when competition is high, the bank takes less risk to achieve higher profitability. It happened in the European banking during global financial crisis. 
The risk taking also related to competition and capital position. Beck, De Jonghe and Schepens (2013) study the impact of competition on risk taking, profitability and risk of failure. They found that higher competition increase banks' fragility because bank take more risk for lowerprofitability. Higher risk taking and systemic fragility are also contributed by how generous is deposit insurance. Further, in a country where credit information sharing exist, banks are taking more risk to get higher profitability.

On the impact of macroeconomic condition, Dietrich and Wanzenried (2014) confirm that banking profitability around the world differs widely as commercial banks have to deal with different macroeconomic environments. The study applies the GMM estimator technique for a large crosscountry data set of commercial banks across 118 countries over the period from 1998 to 2012. They analyse impact of bank characteristics, macroeconomic variables and industry-specific factors on bank profitability. Banks doing business in high-income countries need to be more efficient in order to deal with the lower margins and thus higher efficiency pressure. They confirm that banking profitability around the world differs widely as commercial banks have to deal with different macroeconomic environments. This finding is in line to Freixas and Rochet (2008) that economic variables are significant for bank profit.

Reiterated from the previous studies, we can infer that mostly risk taking has positive impact on profitability and the relationship is endogenous. However, how to measure risk taking is not similar among researchers and neglect the endogeneity. Capital is mostly significant for profitability and negative to risk taking indicating the existence of agency principle. Liquidity is also important factor for bank profitability. In all studies, problem loan is negative to profitability. However, impact of economic variables are not always consistent.

\section{METHODOLOGY AND DATA}

\subsection{Research Framework}

Evaluating bank profitability and risk taking is a complex process that involves assessing interaction between the environment, internal bank condition and external constraints. We approach the problem using Instrumental Variables (2SLS) regression model to capture the endogeneity of risk taking and profit. The primary method of evaluating internal performance is by analysing accounting data. Financial ratios usually provide a broader understanding of the bank's financial condition since they are constructed from accounting data contained on the bank's balance sheet and financial statement. This study is to find a link between bank-specific factors and the economic environment and their impact on risk taking and then on bank performance. The framework basically replicates the work previously done by Dietrich and Wanzenried (2014), Muazaroh et al (2012) and Mongid and Tahir (2011). Dietrich and Wanzelried (2014) apply GMM, in this study, we employ two stage regression popularly known as instrumental variables (2SLS) regression. Estimation is carried out using Stata 10 and follow procedure in Baum (2006).

\subsection{Model}

To examine the determinant of banking profitability applies a two stage regression (2SLS). Model 1 is to evaluate the robustness of risktaking (RT) as instrument variable. Model 2 is to ensure that risk taking (RT) in the OLS is breaching the best linear unbiased estimator (BLUE) assumption as error of risk 
taking (residRT) is contemporerous. Model 3 is the right model to estimate the risk taking-profitability relationship. Model 3 is estimated using limited information 2SLS (Brown, 1990). The relationship between the dependent variable and each independent variable is assumed linear. The model for this study can be formulated as follows:

$$
\begin{aligned}
& \mathrm{RT}_{\text {it }}=\alpha_{0}+\alpha_{1} \mathrm{ETA}_{\text {it }}+\alpha_{2} \mathrm{LAR}_{\text {it }}+\alpha_{3} \mathrm{LLRGL}_{\mathrm{it}}+\alpha_{4} \mathrm{CIR}_{\mathrm{it}}+\alpha_{5} \mathrm{LASSET}_{\text {it }}+ \\
& \alpha_{6} \mathrm{GDPG}_{\mathrm{it}}+\alpha_{7} \mathrm{CBDR}_{\mathrm{it}}+\alpha_{8} \mathrm{CPI}_{\mathrm{it}}+\mathrm{e} \\
& \mathrm{ROA}_{\mathrm{it}}=\alpha_{0}+\beta_{1} \mathrm{SIZE}_{\mathrm{it}}+\beta_{2} \mathrm{ETA}_{\mathrm{it}}+\beta_{3} \mathrm{LAR}_{\mathrm{it}}+\beta_{4} \mathrm{LLRGL}_{\mathrm{it}}+\beta_{5} \mathrm{CIR}_{\mathrm{it}}+ \\
& \beta_{6} \mathrm{RT}_{\mathrm{it}}+\mathrm{Resid}_{\mathrm{RT}}+\mathrm{e} \\
& \text { ROA }_{i t}=\alpha_{0}+\beta_{1} \text { SIZE }_{i t}+\beta_{2} \text { ETA }_{i t}+\beta_{3} \text { LAR }_{\text {it }}+\beta_{4} \mathrm{LLRGL}_{\mathrm{it}}+\beta_{5} \mathrm{CIR}_{\mathrm{it}}+ \\
& \beta_{6}\left(\mathrm{RT}=\alpha 0+\alpha_{1} \mathrm{ETA}_{\mathrm{it}}+\alpha_{2} \mathrm{LAR}_{\mathrm{it}}+\alpha_{3} \mathrm{LLRGL}_{\mathrm{it}}+\alpha_{4} \mathrm{CIR}_{\mathrm{it}}+\right. \\
& \left.\alpha_{5} \mathrm{LASSET}_{\text {it }}+\alpha_{6} \mathrm{GDPG}_{\mathrm{it}}+\alpha_{7} \mathrm{CBDR}_{\mathrm{it}}+\alpha_{8} \mathrm{CPI}_{\mathrm{it}}+\mathrm{e}\right)
\end{aligned}
$$

\subsection{Data and Variables}

There are two types of data for the study. The first is bank level data and the second economic data. Variables employ in this study are derived from theoretical as well as previous empirical studies. These variables are presented in Table 1.

Table 1: Variables, Definition and Sources of Data

\begin{tabular}{cccc}
\hline \hline No & Variable & Definition & Sources \\
\hline 1 & ROAA & Profit Before Tax /Total Asset & BS, IS \\
2 & RT (Risk Taking) & Credit and Operational risk to total asset & BS, IS \\
3 & LASSET & Log Total Asset & BS \\
4 & ETA & Equity /Total Asset & BS \\
5 & LTA & Loan /Total Asset & BS/IS \\
6 & LAR & Liquid asset / Customers' funds & BS \\
7 & CIR & Total expense / Total revenue & IS \\
8 & LLRGL & Loan Loss Reserves / Total Loan & BS/IS \\
9 & CPI & Consumer Price Index & CBI \\
10 & GDPG & Annual Real Economic growth & ADB \\
11 & CBDR & Official Central Bank Rate & CBI \\
\hline \hline
\end{tabular}

Notes: $\mathrm{BS}=$ balance-sheet, IS=IncomeStatement, $\mathrm{ADB}=$ Asian Development Bank, CBI=Central Bank of Indonesia.

Economies of scale are very important concept in economics and it is commonly defined as reductions in the cost per unit of a product because size. When the size or scale is bigger, average cost should be lower. Economic theory suggests that the average cost is lower in line to size and then increases again after a certain level of output decrease again (Stimpert and Laux, 2011). ETA is total Equity (E) divided by Total Assets (TA) indicate capital adequacy of banks. The higher ratio indicates the general safety and soundness of the financial institution. Equity can improve bank safety as it can absorb losses, improve reputation in the market and satisfy the regulator requirement (Berger, Herring and Szegö,1995). Banks with a higher capital ratio are expected to have higher loan growth and profitability both for Islamic and conventional banks (Karim, Hassan, Hassan, and Mohamad (2014).

Risk Taking (RT) is the ratio of the sum of the credit and operational risk exposure divided by Total Assets (TA), It indicates the composition of the bank's risky asset and income. The conversion rates for 
credit risk are $100 \%$ for loan and fixed assets, $20 \%$ for other earning asset. For operational risk, we apply Basic Indicator Approach (BIA) that apply 18\% conversion rate as prescribed by Basel Committee on Banking Supervision (BCBS). Cash and placement in the central bank are excluded. RT provides indicator how much total bank risks compared to total asset. Srairi (2013) state that higher risk taking ratio is assumed better as it provides higher expected income.

The ratio LAR is a liquid asset to customer funds (Liquidity) can be positive or negative to profitability. Banks are legally required by the regulating agencies to keep a minimum amount of liquidity. The aim is to guarantee the availability of liquid funds in case of depositors withdraw their money. These regulations are known as 'legal reserve requirements'. The ratio of legal reserves varies from country to country range from 5\% to $12 \%$. Ahmed (2001) argues that apart from legal reserve requirements, Islamic banks have large amounts of short-term idle balances which earn no return. This cash or liquid asset holding may have two possible impacts on the profitability. As liquid asset, such as cash and placement in the central bank are regarded as non productive assets, it does not produce any return. It means a higher liquid ratio has a negative impact on profitability. In contrast, when a bank has enough liquid assets, the public has a higher trust to the bank and it inhibits customers to save their fund in the bank. If this happened, higher liquid ration increase profitability.

The ratio of loan loss provisions to total gross loans (LLRGL) is usually used as a proxy variable to measure credit risk in ex post definition. The higher LLRGL ratio indicates bank experiencing higher loan default. Under risk management regulation, any decrease in loan quality, bank must put aside some reserves to cover the risk of default. As the non performingloaninformationis not completely available for all banks, we use these variables as a proxy for credit risk. Banking in developing countries such as Indonesia is lending based business. Therefore, the relationship between credit risk and bank profit is expected to be negative.

Economic Growth (GDPG) is an indication whether an economy is growing or not. It should have a positive impact to profitability and risk taking. Inflation (CPI) is expected to produce negative to profitability and risk taking. For the Central Bank discount rate (CBDR) it, we expected to have two possibilities both positive or negative. The study will cover Indonesian banks for the period of 2008-2014.

\section{RESULTS AND DISCUSSION}

\section{1. $\quad$ Data Collection and Processing}

There are 150 bank observations in this study. As this study only uses big banks as sample and excluding regional banks. We choose this approach as a regional bank business model is a little bit unique in term of risk taking behaviour. Regional bank loan exposure is mostly on consumer lending and the customers are mostly government employees which technically zero risk. We also exclude bank with losses as it will disturb the results.

ROAA has mean value 4.98 meaning on average banking firm enjoys $5 \%$ return on asset with variability $3 \%$. Banking firms with higher ROAA is performing better than lower ROAA. ROAA data is not normally distributed based on Shapiro-Wilk normality test. LASSET is generated using logarithm 10 of total assets of each observation. Bank with higher LASSET is better as it can enjoy economies of scale and scope during its operation (Berger and Mester,1997; Altunbas, et.al, 2000, Hughes and Mester, 2013; Trinugroho, Agusman, Tarazi, 2014). The data on LASSET is not normally distributed. 
Finally, ETA is an indicator for capital strength. A higher ratio is better as it has a stronger cushion against loses. The mean is $11 \%$ with a standard deviation around $2 \%$. The ETA is not normally distributed. As most of variables are not normally distributed, we follow Brown (1990) to apply limited insformation 2SLS.

LTA is indicator for credit risk taking. The higher ratio indicates the risk preference of the banking firm in term of credit. In developing countries such as Indonesia, the LTA ratio is high as banking business is lending related. Higher ratio means less business diversification. Trinarningsih, et.al (2016) study the nexus between bank diversification strategy and performance. They find that diversification is negative for performance. On the role of top management team is not having a very strong contribution to diversification strategy and performance. On average, $64 \%$ of bank asset are in the loan, making it prone to credit risk. The minimum is $14 \%$ and the maximum $86 \%$. The data are not normally distributed.

Table 2: Data Description

\begin{tabular}{ccccccc}
\hline \hline No. & Variable & Obs & Mean & Std. dev. & Min & Max \\
\hline 1 & ROAA & 150 & 4.98 & 3.03 & 0.00 & 9.36 \\
2 & RT & 150 & 103.66 & 29.76 & 41.89 & 271.75 \\
3 & LASSET & 150 & 14.86 & 1.54 & 11.22 & 18.07 \\
4 & ETA & 150 & 10.99 & 5.20 & 1.59 & 41.32 \\
5 & LTA & 150 & 63.97 & 11.15 & 14.36 & 85.83 \\
6 & LLRGL & 150 & 2.41 & 1.89 & 0.07 & 11.76 \\
7 & CIR & 150 & 60.68 & 15.27 & 22.82 & 96.59 \\
8 & LAR & 150 & 17.38 & 14.49 & 6.93 & 109.64 \\
9 & CPI & 7 & 7.29 & 3.21 & 3.72 & 11.60 \\
10 & GDPG & 7 & 5.80 & 0.65 & 4.63 & 6.49 \\
11 & CBDR & 7 & 7.27 & 1.33 & 5.75 & 9.25 \\
\hline \hline
\end{tabular}

Note: All measures are in percentage except for log asset which is in nominal

Loan Loss Reserve to Gross Loan (LLRGL) is a measure of ex post credit risk. Although it is not purely $100 \%$ represents the credit risk, the figure is the best available data. The mean value is $2.4 \%$, meaning bank puts a $2.4 \%$ reserve to cover credit risk. In other word, on average, $2.4 \%$ of loan become non performing assets. The figure represents a non performing loan at national level. Maximum LLRGL is around $12 \%$. The data are not normally distributed.

CIR represents the efficiency of the bank operation. The mean value is $61 \%$, meaning that every 100 income generated bank must spend $61 \%$. The minimum is $15 \%$ and maximum is around $97 \%$. The data are not normally distributed. Liquid asset ratio (LAR) represents the liquidity capacity of the banks. The higher the ratio is better, but at the cost of profitability. On average the liquid asset represents $17 \%$ of total customer funds. The data show that minimum is around $7 \%$ and maximum $110 \%$. The data are not normally distributed.

Total risk taking (RT) is risk taking measure. We use it as proxy of risk taking because it looks risk taking as an ex - ante event. Other proxy such as z-score, previously done by Lepetit and Strobel (2013), focus on $e x$-post risk event which is less useful for managerial perspective.It represents a risk weighted asset from credit risk and operational risk. We exclude market risk as it is very low and the data availability. Regulations related market risk taking are very strict. Banks only allow to do a business on exchange rate and interest rate related only. Speculative and commodity trading is prohibited. The mean for total risk taking is $104 \%$ of the total asset. The data are not normally distributed. 
For economic variable (GDPG), the mean for economic growth is $5.8 \%$ with minimum $4.63 \%$ and maximum $6.5 \%$. The policy rate issued by the Central Bank of Indonesia is known as BI- Rate. It should serve as a benchmark rate for all financial asset in Indonesia. The average value is $7.3 \%$ with minimum $5.75 \%$ and a maximum $9.25 \%$. For the CPI (Inflationrate), themean is $7.3 \%$ and maximum value is 11.6\%. CPI and BI-Rate correlated closely. All economic variables are not normally distributed.

Table 3: Correlation among variables

\begin{tabular}{|c|c|c|c|c|c|c|c|c|c|c|c|}
\hline Variable & ROAA & LASSET & ETA & LTA & LLRGL & CIR & LIQRISK & TRISK & EGRW & BIRATE & INFL \\
\hline ROAA & 1.0000 & & & & & & & & & & \\
\hline LASSET & 0.1864 & 1.0000 & & & & & & & & & \\
\hline ETA & -0.2359 & -0.1542 & 1.0000 & & & & & & & & \\
\hline LTA & 0.2285 & -0.2005 & -0.3772 & 1.0000 & & & & & & & \\
\hline LLRGL & -0.2378 & 0.2516 & -0.0143 & -0.2436 & 1.0000 & & & & & & \\
\hline CIR & -0.1636 & -0.4496 & 0.0037 & 0.4443 & -0.0814 & 1.0000 & & & & & \\
\hline LAR & -0.2567 & -0.1780 & 0.9348 & -0.4003 & 0.1543 & 0.0675 & 1.0000 & & & & \\
\hline RT & 0.5143 & -0.2642 & 0.1325 & 0.4728 & -0.2138 & 0.5636 & 0.1311 & 1.0000 & & & \\
\hline EGRW & -0.1363 & -0.0200 & -0.0208 & 0.0541 & -0.0429 & 0.0354 & -0.0008 & -0.0266 & 1.0000 & & \\
\hline BIRATE & -0.9000 & -0.1942 & 0.1851 & -0.0766 & 0.2155 & 0.1723 & 0.1985 & -0.4523 & -0.0708 & 1.0000 & \\
\hline CPI & -0.8239 & -0.1566 & 0.2238 & -0.0310 & 0.1773 & 0.1750 & 0.2235 & -0.3547 & 0.1367 & 0.7935 & 1.0000 \\
\hline
\end{tabular}

From table 3, we can review the correlation between ROA and predictors variable. Four internal variables, the correlation is below 30\%, except for the total risk (RT, risk taking). For the macroeconomic variables, two variables (BIRATE and INFL) are above 30\%. The correlation between risk taking (TRISK) and BIRATE and INFLATION are also very high.

We did estimation of the relationship between ROA and risk taking (RT) using two stage regression for the estimation. The results show that Wald Test is 329 for seven predictors. The result is significant as the Wald Statistics follows an F - distribution. From the estimation. The R-Squared is 59\%, meaning the model can explain the variability of ROA by 59\%. Please note that the sample is only cover big banks, which the account is under BankScope.

Instrumented variable used is risk taking (RT) which consist of credit risk related asset and operational risk related income. We exclude market risk for two reasons: data on this measure is not available and reliable, and the second, the exposure is relatively small for Indonesian banking. We afraid if we include market risk, it will create inconsistency and lead to inconsistent conclusion. Instrumental variables for Risk-taking (TRISK) are LASSET, ETA, LTA, LLRGL, CIR, LAR, GDPG, CBDR and CPI.

From model 1 (Risk Taking Model) we find that risk taking is determined positively by the intermediation ratio (LTA), liquidity risk position (LAR) and negatively economic growth (GDPG), central bank discount rate (CBDR) and price index (CPI). We estimate Model 1 by using Generalized Least Square panel data regression assuming fixed effect as suggested by the Hausman test (Chi-Square $=2.746$ and Prob $>$ Chi2 is 0.12). We find that overall R-Squared is 57\% and Wald Statistic is 172 and significant at $1 \%$. We use this equation for the risk taking model.

Our interest is to test whether profitability is determined positively by bank's risk taking. To do it, we test if profitability is a function of risk taking by regressing the profitability with risk taking and residual of risk taking equation. When both risk taking and residual of risk taking is significant we can assume that the relationship is significant. Our result in Model 2 clearly indicates the relationship. As error(residRT) is also significant, we conclude that the error is contemporarous. It means the OLS 
produce bias estimation and should not be used (Maddala,2001). To solve the problem, we propose equation 3 as the model for the nexus between risk taking and profitability for Indonesia's banking.

Table 4: Result

\begin{tabular}{|c|c|c|c|c|c|c|c|c|c|c|c|}
\hline \multicolumn{4}{|c|}{$\begin{array}{c}\text { Model 1 } \\
\text { Risk Taking Equation }\end{array}$} & \multicolumn{4}{|c|}{$\begin{array}{c}\text { Model 2 } \\
\text { Profitability and Risk Taking with Error }\end{array}$} & \multicolumn{4}{|c|}{$\begin{array}{c}\text { Model 3 } \\
\text { Profitability and Risk Taking In Simultaneous }\end{array}$} \\
\hline Variable & Coef & Z-Value & Sig & Variable & Coef & Z-Value & Sig & Variable & Coef & Z-Value & Sig \\
\hline LASSET & -.91 & -0.49 & 0.623 & LASSET & .68 & 4.40 & 0.000 & LASSET & .18 & 1.48 & 0.138 \\
\hline ETA & .62 & 0.58 & 0.562 & ETA & -.19 & -2.06 & 0.040 & ETA & -.37 & -3.70 & 0.000 \\
\hline LTA & 1.16 & 6.02 & 0.000 & LTA & -.09 & -4.68 & 0.000 & LTA & -.08 & -3.81 & 0.000 \\
\hline LLRGL & -.75 & -0.68 & 0.494 & LLRGL & -.09 & -1.01 & 0.314 & LLRGL & -.19 & -1.79 & 0.074 \\
\hline LAR & .84 & 2.11 & 0.035 & CIR & -.11 & -8.13 & 0.000 & CIR & -.16 & -10.86 & 0.000 \\
\hline GDPG & -4.58 & -2.72 & 0.006 & LAR & -.026 & -0.75 & 0.455 & LAR & .02 & 0.65 & 0.515 \\
\hline CBDR & -6.95 & -4.66 & 0.000 & RTAKING & .14 & 20.19 & 0.000 & RTAKING & .15 & 15.68 & 0.000 \\
\hline CPI & -1.24 & -2.19 & 0.028 & residRT & -.09 & -6.35 & 0.000 & Constant & 6.05 & 2.39 & 0.017 \\
\hline Constant & 108.11 & 2.93 & 0.003 & Cosntant & -4.68 & -1.65 & 0.100 & & & & \\
\hline $\mathrm{N}$ & & 150 & & $\mathrm{~N}$ & & 150 & & $\mathrm{~N}$ & & 150 & \\
\hline R square & & 0.63 & & $\mathrm{R}$ square & & 0.89 & & $\mathrm{R}$ square & & 0.59 & \\
\hline $\mathrm{F}(8.141)$ & & 29.56 & & $\mathrm{~F}(8.141)$ & & 141.06 & & $\mathrm{~F}(8.141)$ & & 329.57 & \\
\hline
\end{tabular}

Before using model 3 for analysis, we have to ensure that the condition for Instrumental variables (2SLS) regression. The main question is whether a variable (RT) presumed to be endogenous in fact is exogenous. If it is the case, then the OLS regression is more efficient. To ensure it, three tests must be performed. The first is first stage test. From the first-stage regression summary statistics, we find that minimum eigenvalue statistic $(\mathrm{F}, 3,140)$ is 66.4503 . The Wald test is 22.30 meaning the hypothesis that the instrument is weak is rejected. The second, we do test of endogeneity by assuming the variables risk taking (RT) is exogenous. From the Wu-Hausman statistics $(1,141)$ is 304 and significant $1 \%$. It means the risk taking (RT) is endogenous. The third is tests of over identifying restrictions. The Ho is the model is identified. From the Sargan score test, we find the Chi-squared is 2.250 with p-value 0.3246. Using Basmann Chi-squared test, the result is 2.132 with p-value 0.3444. It means the model is identified. In short, the nexus between risk taking and profitability is significant and confirming the endogeneity relationship between risk taking and profitability in Indonesia's banking.

\subsection{Discussions}

As our focus is on the impact of risk taking on bank profitability, we apply model 3 for further analysis. We simulated estimation using state ownership dummy, however it is not significant. Model 3 in the Table 4 is the best attainable. The coefficient for the Total Risk Taking (RT) variable is 0.148 and significant at $1 \%$. Any increase RT will improve bank profitability. It means that risk taking implies positive to profitability higher risk taking bring higher profitability. This finding consistent with Markowitz (1959) presumption that high risk high return. The consistency is a result of the definition of risk taking. Our study focus risk taking as ex-ante risk, it is technically still a potential risk. It is different from other measure of risk, such as NPL. Their relationship is negative because the risk is defined as risk event or ex post. Ex-post definition of risk implied risk as an expense or cost. The definition of risk taking as ex-ante should be noted as more valid for bank profitability. Management bank, in their decision making framework, always refer to ex-ante, as risk taking is for taking opportunity. This finding may explain why Trinarningsih et al (2016) did not find the contribution of the top management team (TMT) role on bank risk taking.

The finding is in line to Cole, Kanz and Klapper (2015) that conclude that motivation of higher risk taking is for profit. Using a loan officer (A/O) as samples, they find that $\mathrm{A} / \mathrm{O}$ take higher risk to improve performance so they will get promoted. This behaviour is similar to bank management at the top level 
that higher risk taking is more for personal reasons than for shareholders. When higher risk taking is successful, decision makers will personally enjoy the benefits. When it is failing, shareholders or top management will incur the cost. Laeven and Levine (2009) show that incentive motive and moral hazard due to deposit insurance or too big to fail (TBTF) are the core sources for higher risk taking. This result confirms that profit motive is very strong and the nexus between the risk taking and the profitability is confirmed. It means, the motive to generate more income is the determinant of risk taking.

Size (LASSET) measured by log asset is positive. The coefficient is 0.18 . It means there is tendency that higher size means higher profit. The Size is not significant. The result underline the size is not everything in the banking business. Benefit of size in economic theory is economies of scale and scope. However result shows that size is not always means higher profit because profitability id more on management quality than size. Efficiency is seeming more important than size. Benefits of economies of scale and scope are not always enjoyable when the management quality is not good.

There is a general convention among researchers that the relationship between size and efficiency and profit is not fully linear. The relationship is U-shape meaning that small banks are less efficient due to size. Small banks have the potential to improve their efficiency and profitability by increasing the size. Medium size banks enjoy better efficiency. Largest bank is inefficient because of its rigidity in their business model. We suspect that the reason for insignificant of variable size due to the linearity of the approach we used. Study by Trujillo-Ponce (2013) benefit of scale efficiency due to size.

ETA is negative and significant. The result is very surprising because bigger banks should earn higher profit. However, the result is negative implied less capital is more profitable. Many studies show that higher equity is linked to lower risk taking. Bank with higher capital take less risk as shareholder prefers stable profit than high but not stable. This rational among highly capitalized bank to take less risk because they are required to be prudent. Theory moral hazard also explain the finding because the well capitalized banks will absorb the loss of their capital. It is different from the less capitalized bank, which prefer to have higher risk because if they make higher profits, they will enjoy. At the same time when they make huge loss, deposit insurance company or taxpayers will pay the cost.

LTA is credit risk taking (ex ante). The coefficient is negative 0.08 and significant at $1 \%$. It means higher credit to total asset ratio do not improve the profitability. This result is in line to Sutaryo, et.al (2016) that state banks make less loan. In Indonesia, big banks generally produce less loan to total assets than smaller banks.

LLRGL is indication of credit risk event (ex post). It is the funds dedicated to absorb the loss from a loan. However, although the rule to put LLR is clear, management of the bank still intervene to put more or less. However, LLR is a very good indicator for bank's loan quality. The coefficient is negative and significant. It means higher loan loss reserve reduces bank profitability as LLR is the cost of the bank. When LLR increase by $1 \%$ bank profit will reduce by $0.17 \%$. The result confirms that loan quality is an important determinant for bank profit. Ability of bank management to reduce LLR will bring a substantial increase in profitability without any increase in effort and cost of capital.

CIR is accounting measure of bank efficiency. Efficiency determines bank profitability. However the CIR is not an efficiency ratio, but inefficiency one. Higher ration means higher cost inefficiency. The result is consistent with our expectation that bank inefficiency reduces bank profitability. When a bank experiences one percent increase in inefficiency, its profit will decrease by $0.17 \%$. Olson and Zoubi 
(2011) support the finding that efficient banks enjoy higher profitability in the MENA region. Bank with higher efficiency score tend to be more efficient and enjoy better profitability. The finding implies that effort to improve efficiency should be done.

Liquidity is positive to profitability. The coefficient is 5.27 but not significant. The result underline the important in liquidity management among big banks in Indonesia. Although it can be viewed contradiction with the liquidity theory which stated less liquidity means more fund to be invested in productive sector and more profit. The reason behind the situation may come from the imperfection of the money market. Cost of borrowing in the market can fluctuate sharply and it will damage the bank. In the modern management, capability to manage liquidity is essential determinant of bank to survive in the contestable market.

Good liquidity management, as shown in higher liquidity availability, improve profitability because the bank can use its resources better. The bank has reduced the reliance on money market as it is riskier and may have to pay higher interest rate for liquidity support. For Indonesian bankers, the theory states that less liquid asset means higher profit may not always valid. The Global Financial Crisis in 2008 teaches bank management to be aware with liquidity problems. Although not significant, the lesson is to prepare liquidity shortage using its own asset. A Good management practice is not relying the sources of liquidity from the market as the market liquidity can fluctuate significantly. The bank management should not assume the market for liqudity is stable and relying on the possible support from the central bank (the lender of the last resort)

In short, the result of the underline the validity of the relationship between risk taking and profit as positive relationship when risk is measured using ex-ante approach. This research should add new understanding among researchers and bank regulator that for purposes of supervision or risk management, this new measure of risk taking should be used. Unfortunately, most previous studies focuses on risk taking as ex-post. This approah provides opposite implication for bank management. Recent studies on risk focus risk taking mostly apply NPL and Z-score as risk measure. The ex-post risk event can not provide insight on risk taking behaviour as basically ex-post risk is accident event. Previous studies, such as Cole, Kanz and Klapper (2015), have noted that motivation for a higher risk taking is for future profit. Using Markowitz's framework (Markowitz, 1956), it is rational to increase profits by taking more risk. Regulators and shareholders should apply the concept of risk taking as $e x$ ante risk taking as they are more concern on future event than the ex-post event.

This finding also stresses the quality of management in making a profit, which is represented by better liquidity management, efficiency and risk taking. Note to say is better at managing risk and operation may result higher profit than taking on more risk.

\section{CONCLUSION AND IMPLICATION}

This study examines the relationship between bank risk taking and profitability of Indonesian banking. Differ to previous studies, We define risk taking using ex ante risk. It is the summation of credit risk weighted asset and operational risk weighted asset. The study period is from 2008-2014 and cover 150 big banks. Two stage regression technique applied. Overall, the findings suggest that risk taking and profitability relationship is endogeneus, positive and significant. Surprisingly, capital is negative and significant underlying the optimal capital theory and too prudential behaviour. Credit risk is negative and significant supporting high credit risk in Indonesia. The cost efficiency is also significant and 
stronger than market power hypothesis. The managerial implication fromt his paper is a better bank management seems better than taking a higher risk in pursuing higher profitability.

\section{ACKNOWLEDGEMENT}

Researchers acknowledge the financial support from the Ministry of Research, Technology and Higher Education (Ristekdikti) of Indonesia, under the Fundamental Research Grant Scheme (FRGS) Contract 060/SP2H/P/K7/KM/2015

\section{REFERENCES}

Abdul Wahab, H., Saiti, B., Rosly, S. A., \& Masih, A. M. M. (2017). Risk-Taking Behavior and Capital Adequacy in a Mixed Banking System: New Evidence from Malaysia Using Dynamic OLS and Two-Step Dynamic System GMM Estimators. Emerging Markets Finance and Trade, 53(1), 180198.

Abreu, M., \& V. Mendes.(2002), Commercial Bank Interest Margins and Profitability: Evidence From Some E.U. Countries, University of Porto Working Paper Series, No. 122.

Agarwal, V., \& Taffler, R. (2008). Comparing the performance of market-based and accounting-based bankruptcy prediction models. Journal of Banking \& Finance, 32(8), 1541-1551.

Ahmed, O. B. (2001). Islamic Equity Funds: The Mode of Resource Mobilization and Placement. Jeddah: Islamic Research and Training Institute, Islamic Development Bank.

Altunbas, Y., Liu, M. H., Molyneux, P., \& Seth, R. (2000). Efficiency and risk in Japanese banking. Journal of Banking \& Finance, 24(10), 1605-1628.

Ascharya, V., \& Naqvi, H. (2012). The seeds of a crisis: A theory of bank liquidity and risk taking over the business cycle. Journal of Financial Economics, 106(2), 349-366.

Athanasoglou, P. P., Brissimis, S. N., \& Delis, M. D. (2008). Bank-specific, industry-specific and macroeconomic determinants of bank profitability. Journal of international financial Markets, Institutions and Money, 18(2), 121-136.

Baum, C. F. (2006). An Introduction to Modern Econometrics Using Stata. Texas: Stata Press Publication.

Beck, T., De Jonghe, O., \& Schepens, G. (2013). Bank competition and stability: Cross-country heterogeneity. Journal of Financial Intermediation, 22(2), 218-244

Berger, A. N., \& Mester, L. J. (1997). Inside the black box: What explains differences in the efficiencies of financial institutions? Journal of banking \& finance, 21(7), 895-947.

Berger, A. N., Herring, R. J., \& Szegö, G. P. (1995). The role of capital in financial institutions. Journal of Banking \& Finance, 19(3-4), 393-430

Berger, A. N., Klapper, L. F., \& Turk-Ariss, R. (2009). Bank Competition and Financial Stability. Journal of Financial Services Research, 35(2), 99-118.

Bhattacharya. S., \& Thakor, A. V. (1993). Contemporary Banking Theory. Journal of Financial Intermediation, 50(3), 2-50

Booth, G. G., Fung, H. G., \& Leung, W. K. (2016). A risk-return explanation of the momentum-reversal "anomaly". JournalofEmpirical Finance, 35(January), 68-77.

Brown, R. L. (1990). The robustness of 2SLS estimation of a non-normally distributed confirmatory factor analysis model. Multivariate behavioral research, 25(4), 455-466.

Cole, S., Kanz, M., \& Klapper, L. (2015), Incentivizing Calculated Risk-Taking: Evidence from an Experiment with Commercial Bank Loan Officers. The Journal of Finance, 70(2), 537-575. 
Diamond, D. W., \& Rajan, R. G. (2000). A Theory of Bank Capital. The Journal of Finance, 55(6), 2431-2465.

Dietrich, A., \& Wanzenried, G. (2011). Determinants of bank profitability before and during the crisis: Evidence from Switzerland. Journal of International Financial Markets, Institutions and Money, 21(3), 307-327.

Dietrich, A., \& Wanzenried, G. (2014). The determinants of commercial banking profitability in low-, middle-, and high-income countries. The Quarterly Review of Economics and Finance, 54(3), 337354.

Fadzlan, S., \& Kahazanah, N. B. (2009). Determinants of Bank profitability in a Developing Economy: Empirical evidence from the China Banking Sector. Journal of Asia-Pacific Business, 10(4), 201307.

Foos, D., Norden, L., \& Weber, M. (2010). Loan growth and riskiness of banks. Journal of Banking and Finance, 34(12), 2929-2940.

Freixas, X., \& Rochet, J. C. (2008). Microeconomics of banking. Cambridge: MIT press.

Gallati. R. (2003). Risk Management and Capital Adequacy. New York: McGraw Hill

Gambacorta, L., \& Mistrulli, P.E. (2004). Does bank capital affect lending behaviour? Journal of Financial Intermediation, 13(4), 436-457.

Godlewski, C. J. (2006). Regulatory and Institutional Determinants of Credit Risk Taking and a Bank's Default in Emerging Market Economies: A Two-Step Approach. Journal of Emerging Market Finance, 5(2), 183-206.

González, F. (2005). Bank regulation and risk-taking incentives: An international comparison of bank risk. Journal of Banking and Finance, 29(5), 1153-1184. http://doi.org/10.1016/j.jbankfin.2004.05.029

Greuning, H., \& Bratanovic, S. B. (2009). Analyzing Banking Risk: A Framework for Assessing Corporate Governance and Risk Management. ( ${ }^{\text {rd }}$ Edition). Washington, USA: The World Bank.

Hughes, J. P., \& Mester, L. J. (2013). Who said large banks don't experience scale economies? Evidence from a risk-return-driven cost function. Journal of Financial Intermediation, 22(4), 559-585.

Karim, M. A., Hassan, M. K., Hassan, T., \& Mohamad, S. (2014). Capital adequacy and lending and deposit behaviors of conventional and Islamic banks. Pacific-Basin Finance Journal, 28(June), 58-75.

Konishi, M., \& Yasuda, Y. (2004). Factors affecting bank risk taking: evidence from Japan. Journal of Banking And Finance, 28(1), 215-232.

Laeven, L., \& Levine, R. (2009). Bank governance, regulation, and risk taking. Journal of Financial Economics, 93(2), 259-275.

Lee, S. W. (2008). Asset size, risk-taking and profitability in Korean banking industry. Banks and Bank Systems, 3(4), 50-54.

Lepetit, L., \& Strobel, F. (2013). Bank Insolvency Risk and Time-Varying Z-Score Measures. Journal of International Financial Markets, Institutions and Money, 25(July), 73-87.

Maddala, G. S. (2001). Introduction to Econometrics. In G. S. Maddala (3 ${ }^{\text {rd }}$ Edition.), Simultaneous Equations Models (pp. 343-390). New York: Wiley.

Markowitz, H. (1959). Portfolio Selection: Efficient Diversification of Investment. New York: John Wiley \& Sons

Miles, D., Yang, J., \& Marcheggiano, G. (2013). Optimal bank capital. The Economic Journal, 123(567), 1-37.

Mongid, A., \& Tahir, I. M. (2011). Impact of corruption on banking profitability in ASEAN countries: An empirical analysis. Banks and Bank Systems, 6(1), 41-48. 
Mongid. A., \& Santoso, W. (2002). Linking Accounting Data to Prudential Measure: Adjusted Profitability and Risks in Indonesian Banks. Journal of Economics, Business, \& Accountancy: Ventura, 5(2), 196-206

Muazaroh, Eduardus, T., Husnan, S., \& Hanafi, M. M. (2012). Determinants of Bank Profit Efficiency: Evidence from Indonesia. International Journal of Economics and Finance Studies, 4(2), 163-173.

Olson, D., \& Zoubi, T. A. (2011). Efficiency and bank profitability in MENA countries. Emerging market review, 12(2), 94-110.

Petria, N., Capraru, B., \& Ihnatov, I. (2015). Determinants of Banks' Profitability: Evidence from EU 27 Banking Systems. Procedia Economics and Finance, 20(15), 518-524.

PwC. (2015). Indonesia Banking Survey 2015. Indonesia: PwC Indonesia.

Rodríguez-Ruiz, Ó., Rodríguez-Duarte, A., \& Gómez-Martínez, L. (2016). Does a balanced gender ratio improve performance? The case of Spanish banks (1999-2010). Personnel Review, 45(1), 103120.

Saha, A., Ahmad, N. H., \& Yeok, S. G. (2016). Evaluation of Performance of Malaysian Banks In Risk Adjusted Return on Capital (Raroc) and Economic Value Added (Eva) Framework. Asian Academy of Management Journal of Accounting \& Finance, 12(1), 25-47.

Santos. J. A. C. (2000). Bank capital regulation in contemporary banking theory: a review of the literature. BIS Working Papers No. 90.

Schaeck, K., \& Cihák, M. (2014). Competition, efficiency, and stability in banking. Financial Management, 43(1), 215-241.

Shen, C. H., Chen, Y. K., Kao, L. F., \& Yeh, C. Y. (2009). Bank liquidity risk and performance. Paper presented at the 17th Conference on the theories and practices of securities and financial markets, Hsi-Tze Bay, Kaohsiung, Taiwan.

Srairi, S. (2013). Ownership structure and risk-taking behaviour in conventional and Islamic banks: Evidence for MENA countries. Borsa Istanbul Review, 13(4), 115-127. http://doi.org/10.1016/j.bir.2013.10.010

Stimpert, J. L., \& Laux, J. A. (2011). Does Size Matter? Economies of Scale in the Banking Industry. Journal of Business \& Economics Research, 9(3), 47-56.

Sutaryo, S., Prakosa, B. G., Trinugroho, I., Prabowo, M. A., \& Hakim, A. R. (2016). Political cycles and lending behavior of state-owned banks: The case of Indonesia. Advanced Science Letters, 22(5-6), 1742-1744.

Tahir, I. M., \& Mongid, A. (2013). The Interrelationship between Bank Cost Efficiency, Capital and Risk-Taking in ASEAN Banking. International Journal of Economics and Management Sciences, 2(12), 1-15.

Tan, Y., \& Floros, C. (2012). Bank profitability and GDP growth in China: a note. Journal of Chinese Economic and Business Studies, 10(3), pages 267-273.

Trinarningsih, W., Husa, P. P., Untoro, W., Trinugroho, I., \& Sutaryo, S. (2016). Diversification and bank performance: Do TMT characteristics matter? Advanced Science Letters, 22(5-6), 16511653.

Trinugroho, I., Agusman, A., \& Tarazi, A. (2014). Why have bank interest margins been so high in Indonesia since the 1997/1998 financial crisis? Research in International Business and Finance, 32(August), 139-158.

Trujillo-Ponce, A. (2013). What determines the profitability of banks? Evidence from Spain. Accounting \& Finance, 53(2), 561-586.

Watanabe, W. (2007). Prudential regulation and the 'credit crunch': Evidence from Japan. Journal of Money, Credit and Banking, 39(3), 639-665. 